Article

\title{
Love Jihad in Contemporary Art in Norway
}

\author{
Ragnhild Johnsrud Zorgati
}

check for

updates

Citation: Zorgati, Ragnhild Johnsrud. 2021. Love Jihad in Contemporary Art in Norway. Religions 12: 1106. https://doi.org/10.3390/rel12121106

Academic Editors: Iselin Frydenlund and Eviane Leidig

Received: 20 September 2021

Accepted: 23 November 2021

Published: 15 December 2021

Publisher's Note: MDPI stays neutral with regard to jurisdictional claims in published maps and institutional affiliations.

Copyright: (C) 2021 by the author. Licensee MDPI, Basel, Switzerland. This article is an open access article distributed under the terms and conditions of the Creative Commons Attribution (CC BY) license (https:/ / creativecommons.org/licenses/by/ $4.0 /)$.
Department of Culture Studies and Oriental Languages, University of Oslo, 0316 Oslo, Norway; r.j.zorgati@ikos.uio.no

\begin{abstract}
This article explores the concept of 'love jihad' and the love jihad discourse in a Scandinavian setting, with a particular emphasis on contemporary works of art and popular culture in Norway. Arguing that 'love jihad' may be understood as part of a larger cluster of meaning related to fear of love across religious and cultural boundaries, and of losing 'our women' to 'foreign men', the article demonstrates that the love-jihad discourse and its related tropes exist in the Norwegian public sphere. It is directly articulated in far-right blogs and Facebook groups and indirectly present in the works of art and popular culture that this article explores. Indeed, read intertextually and in light of recent research in sociology and media studies about Islamophobia and anti-Muslim rhetoric on the Internet, works such as Disgraced, Heisann Montebello, SAS plus/SAS pussy, and Norskish demonstratethrough challenging, mocking or discussing the love-jihad discourse — that 'love jihad' has echoes in contemporary Norway.
\end{abstract}

Keywords: love jihad; Norway; islamophobia; art works

\section{Introduction}

What does 'love jihad', a concept coming from India, have to do with Scandinavian, or more particularly, Norwegian social and cultural realities? In line with the editors of this special issue,'Love Jihad': Sexuality, Reproduction and the Construction of the Predatory Muslim Male', I understand love jihad 'as the notion that Muslim men strategically allure and entrap non-Muslim women with the intent to marry and convert them to Islam as part of an Islamization project' (Frydenlund and Leidig, forthcoming). I further argue that love jihad is part of a larger cluster of meaning related to fear of love across religious and cultural boundaries, and of losing 'our women' to men of another group. This pattern is deeply rooted in different patriarchal cultures as anthropologists and historians have demonstrated, and as will be discussed at the end of this article. I conceive of love jihad as one variant of this fundamental pattern; a variant which is particularly targeting Muslim men in the postcolonial and globalized twenty-first-century world and which is part of a network of interrelated anti-Muslim tropes.

My main focus will be on how the love-jihad discourse and related tropes come to the fore in contemporary Scandinavian works of art and popular culture. Given the patriarchal mind set/value system which underpins the love-jihad discourse, it is interesting to explore whether it still reverberates in postmodern, secular Scandinavia, where one important societal value is equality; gender equality being particularly stressed. Hence, my main interest in this article revolves around the following questions: Does the love-jihad discourse exist in Scandinavia? Is it articulated in the public domain? Are there echoes of the love-jihad discourse in Scandinavian art and popular culture? Given my argument that the love-jihad discourse has marked patriarchal cultures throughout history, I am also interested in examining in what way historical references are inserted into the art works I explore.

My contribution draws inspiration from studies of popular culture within the study of religion (Endsjø and Lied 2011) and from research on Islam in Europe; a pluridisciplinary field, ${ }^{1}$ which in recent years has seen a growing interest in art and popular culture (Peter 
et al. 2013). ${ }^{2}$ I also draw on insights from scholars in the field who have studied the intricate ways of how Islam, through public controversy, takes shape in Europe (Göle 2013; Lundby 2017). Art and popular culture are evidently part of the public domain as artists share their thoughts, viewpoints, and visions with their audiences. Public is also the critical reception of their work, which, especially when virulent, testifies to the societal significance of these works. More profoundly, I share the contention that works of art and popular culture often seize-in a crystallized, compressed manner-the quintessence of social patterns, values, and conflicts that operate in a given society (LeVine 2020; Van Nieuwkerk 2012).

The theatre play, music videos, and TV-series that I refer to in this article influenced the Norwegian public sphere between 2015 and 2021. They address the issue of Islam in Europe or America, discuss questions of racism, xenophobia, and Islamophobia, and put on stage or explore different aspects of interfaith love, directly or indirectly evoking prejudices close to those incarnated in the love-jihad discourse.

First, I dwell on Disgraced by the American playwright Ayad Akhtar, which was translated into Norwegian and performed at the National Theatre (Nationaltheatret) in Oslo in 2019. The play provoked a heated debate among critics in some of Norway's most influential newspapers about the relevance of the play in a Norwegian context, resulting in a discussion that finally engaged the playwright himself. In addition, prompted by the play, the theatre arranged public talks, and students at the University of Osloorganized a seminar about the history of antisemitism and Islamophobia entitled 'Phobias and Persecution: Antisemitism and Islamophobia Past and Present: A Panel Discussion on Current Issues using the Play Disgraced as a Starting Point ${ }^{3}$ The discussion engaged the dramaturge of the play, a historian of the Holocaust, and a scholar of religion specializing in medieval and early modern Iberian history to discuss how the past talks to the present.

The second type of works I address are the music projects Heisann Montebello (20152017) and SAS Plus/SAS Pussy (2019) by the Norwegian rap duo Karpe. ${ }^{4}$ Karpe, earlier Karpe Diem, is one of Norway's most celebrated rap groups. They have won several prestigious prizes for their music and lyrics and are known for their innovative scenic shows and the pictorial universes they create in their videos and film projects. ${ }^{5}$ The artists, Magdi and Chirag, are socially and politically engaged with regard to questions of integration, racism, xenophobia, and Islamophobia, and their utterances in the media have not, as I will demonstrate below, gone unnoticed, neither by politicians nor their female colleagues in the music industry. Karpe often refer to religion in their projects, evoking their own composite backgrounds. Chirag is of Hindu and Indian descent, while Magdi is a Muslim whose family tree comprises Norwegian and Egyptian ancestors (Sandve 2015; Jacobsen and Vestel 2018).

The last work I analyse is the TV-series Norskish aired by the Norwegian Broadcasting Corporation (NRK) in 2021. It is one of several series made by the public broadcaster in the wake of the international success Skam [Shame] that describes the lives of youth and young adults in the plurireligious, pluricultural, and class-divided Norwegian capital. ${ }^{6}$ These series address issues of fragile identities—secular or religious - and raise thorny questions about integration and outsiderness, belonging and alienation, freedom and control.

Overall, the three works I explore testify to a Norwegian public sphere where questions of religion, and especially of Islam, are increasingly raised within art and popular culture. When Dag Endsjø and Liv Ingeborg Lied wrote their seminal book about religion and popular culture in 2011, they had difficulties in finding examples of Islam or Muslims in the Norwegian media landscape (Endsjø and Lied 2011). ${ }^{7}$ Today, ten years later, references to Islam and Muslim cultures are multiple: in pieces of art, popular culture, theatre plays, films, and literary fiction, a development that I explore in the research project Mobile Muslims and Invisible Islam. ${ }^{8}$ The three works I have selected for this particular contribution raise interesting questions about love across religious and cultural divides and address issues related to the love-jihad discourse and its related tropes. All three form an opposition to the 'Islamophobia cluster of meaning'; still, they express anxiety with regard to crosscultural and cross-religious love. 
Methodologically, the article is posited in the intersection of the study of religion's emphasis on comparison and comparative literature's focus on hermeneutics, close reading, and intertextuality. Inspired by Julia Kristeva and M. M. Bakhtin, I understand intertextuality as the idea that texts call upon, echo, or engage in dialogues with other texts across geographic frontiers, historical epochs, and disciplinary divisions (Bakhtin [1986] 2002). Texts are here understood in the broader sense to include images and soundscapes. More precisely, through close readings of selected works of art and popular culture, I identify recurrent tropes: for example, the blonde woman, the violent Muslim male, and the oppressed Muslim woman; tropes that are also characteristic of the anti-Islam discourse found on far-right social media platforms, as studied by the Norwegian sociologist Katrine Fangen and the Finnish sociologist and media scholar Katrine Horsti (Fangen 2020; Horsti 2017). The identification of tropes is thus the result of what I call a horizontal process of comparison where I compare the contemporary art works with one another, reading them in light of insights from sociology and media studies. In addition, I conduct a vertical comparison when I use knowledge of history as an interpretive perspective on the works of art. This historical 'perspectivation' / putting into perspective is not arbitrary, however, but responds to topics evoked in the respective art works. Disgraced invites particularly to a comparison between plural societies post $9 / 11$ and plural societies in early modern Iberia, since there are direct references to both periods in Akhtar's play. Overall, it is my contention that belief in the merits of unconscious or conscious strategies of comparison underpins the idea of the current thematic volume of Religions, which seeks to disclose how 'love jihad' moves, as a travelling trope.

Before I delve into the art works, however, I will present some examples of Scandinavian voices who believe in the love-jihad trope, fear a Muslim take-over of Europe, and do not exclude the veracity of Eurabia theories. This review also serves to contextualize my reading of the selected works of art.

\section{Contexts: Love-Jihad Discourse on the Far Right}

Recent investigations in sociology and media studies demonstrate that there are voices on the far right in Scandinavia who would adhere to the idea that Muslim men strategically marry (or rape) non-Muslim women in order to convert them to Islam and enroll coming children into the Muslim fold, thereby expanding the umma, the community of believers, at the expense of other communities. Actually, in a Scandinavian context, the non-Muslim women are depicted as young, innocent, often blonde bearers of the nation's essence who must be shielded from rampant immigration and from brutal and violent Muslim men. At the same time, and contradictorily, the far right tend to cite Scandinavian ideals of gender equality in their critique of Islam. The image of Norwegian and Swedish girls as threatened by immigration and in need of protection from the abuse of Muslim men thus spills right into the love-jihad discourse: 'our women' are vulnerable to the penetration of outsiders and must be protected.

In 'Gendered Images of Us and Them in Anti-Islamic Facebook Groups', Katrine Fangen examines gender aspects of anti-Muslim discourses in two Facebook groups on the far right in Norway, demonstrating that the groups take part in a transnational network of Islamophobic imaginaries and ideas One group counts approximately 14,000 members, the other just above 3500 (Fangen 2020). ${ }^{9}$ In following different discussion threads in the open groups, Fangen observed that 'in both groups the majority of the debates revolve around Muslims and Islam, and are marked by critical, scornful, stigmatizing and generalizing treatment' (Fangen 2020, p. 457). Moreover, 'gender themes proved to be a dominant topic in both groups' (Fangen 2020, pp. 457-58).

Drawing on Sara Farris' concept of femonationalism, which 'refers to the exploitation of feminist themes in anti-Islam campaigns and the stigmatization of Muslim men under the banner of gender equality', Fangen emphasises that there is a general trend among populist right-wing parties in Europe to embrace gender equality and freedom of speech as core values in their definition of national values and in their criticism of Islam (Fangen 2020, 
p. 455). Fangen's analysis concurs with that of the Finnish sociologist and media scholar Karina Horsti, who affirms that "nationalist, right wing parties and "counter-Jihadist" movements ... have brought the rights of women and LGBT people to the centre of their politics. These groups often claim that Muslims are inherently patriarchal and backward; therefore, they threaten liberal values, particularly the rights of women, gay and lesbians' (Horsti 2017, p. 1443).

Horsti has studied the circulation in social media of an image of a blonde Swedish woman who was the victim of a violent assault. The original image, a forensic photograph, was soon turned into a meme, which went viral on the social media platforms of the far right. In tracing the history of this image/meme, Horsti shows that the forensic image was first published in mainstream Swedish newspapers with the consent of the victim who wanted her picture published as a general token of how 'brutal violence against women could be' (Horsti 2017, citing the victim Lisa in Expressen, 26 March 2005). She and her friend had been attacked on their way home late at night and her friend was raped. The woman who agreed to have her photo published by regular media had no intention of contributing to hatred of foreigners or Muslims. Nevertheless, her original message was soon transformed and the Somali background of the attackers was brought into the limelight when the Norwegian nationalist blogger Fjordman-who functioned as a nodal point and translator between the Scandinavian and the English speaking blog spheres (Horsti 2017, p. 1445)_framed the image as an example of ethnic violence, testifying to the 'Muslim rape epidemic' or 'rape jihad'; common myths in Islamophobic circles worldwide (Horsti 2017, pp. 1442, 1445).

In the imagery of the far-right groups, the reversed image of the vulnerable Scandinavian girl is the violent Muslim male (Fangen 2020, p. 460). Muslim men are seen as savage and violent 'wildmen', driven by insatiable sexual appetites (Fangen 2020, pp. 465-66). Moreover, they cannot be tamed (integrated) and thus 'castration or deportation are the only solutions to the danger posed by Muslim men' (Fangen 2020, p. 465). ${ }^{10}$ Muslim men are also perceived as a threat to Muslim women, who are characterized as oppressed, deprived of agency, and as silently consenting to their own oppression-the hijab being the symbol of such 'self-chosen' subjugation (Fangen 2020, p. 463). If 'they are kept in the dark' and are 'totally ignorant', as one commentator suggested, it is a result of their own choices. In contrast, white men are thought to be gentler to women and in favour of gender equality.

Fangen argues that such racialized stereotypes remount to Orientalist imaginaries, opposing the civilized white male who is in control of his own emotions to the barbarian uncivilized, native - in this case the Muslim - who is the victim of his emotions and instincts (Fangen 2020, pp. 465-66). Horsti notes similar stereotypes in her corpus. 'The bloggers believe that Muslim men, as an ethnic group, violently rape non-Muslim, unveiled women and that this is a problem that has not been addressed in the West due to feminism' (Horsti 2017 , p. 1449). Indeed, the groups hold an ambivalent image of Scandinavian women who they depict either as innocent blondes in need of protection or as multiculturalist feminists; traitors who have opened the country for Muslim immigration. Horsti concludes that the combined fear of Muslims and feminists is widely embraced by anti-Jihadi and far-right networks worldwide:

The image [of the blonde woman] visualizes the different fears that cut across the trope of 'Muslim rape' in transnational, exclusionist spaces. In circulating this picture, the bloggers imagine a shared White community in danger, symbolized by the injured, blonde, Swedish woman, who is in need of global protection ... Paradoxically, however, the figure of the Swedish woman also symbolizes emancipation, feminism, and female agency at the frontline of society, which the bloggers consider to be destructive to (White) masculinity. (Horsti 2017, p. 1441)

To sum up, the following tropes infuse the Scandinavian variant of the love-jihad discourse: the oppressed Muslim woman, the dangerous Muslim man, the blonde, white woman, and the gentle, but threatened white man. Muslim women are oppressed and 
responsible for their own oppression, thus they are irrational and not to be trusted; Muslim men are sexually insatiable wild men, thus irrational, and thus representing an even greater threat to 'our women'. Scandinavian women are either feminist traitors or vulnerable girls. Their blondeness is ambiguous as it displays emancipation and sexual liberation on the one hand, innocence and vulnerability on the other. In the following section, I will analyse how contemporary art in Norway thematises, discusses, or mocks the love-jihad discourse and its concurrent tropes.

\section{Interfaith Love in Contemporary Art in Norway}

\subsection{Disgraced}

Love across ethnic, religious, and cultural boundaries constitutes a recurrent theme in art works that have influenced the Norwegian cultural scene in the last five years. In 2019, the National Theatre in Oslo staged Krenket-the Norwegian translation of Disgraced ${ }^{11}$ - the acclaimed play by the American playwright Ayad Akhtar. ${ }^{12}$ Although the original setting of the piece is in New York post 9/11, its reception by Norwegian theatre critics testifies to its relevance in the current Norwegian public sphere.

In Disgraced, the four main protagonists, upcoming young people in Manhattan's financial and artistic milieus, form two cross-religious and cross-ethnic couples in an intersection of ethnic, religious, class, and racial identities (Putri and Destari 2019). The art curator, Isaac, a Jew, is married to Jory, a lawyer of Afro-American descent, while the main character Amir, also a career jurist, is an apostate from Islam who is married to Emily, a white artist (probably WASP). ${ }^{13}$ Amir is highly critical of Islam, which he characterizes as a tribal, patriarchal, and violent religion. He has taken on a Hindusounding name, Kapoor, because it carries less stigma in North America post 9/11, than his family name Abdullah (from Pakistan). Contrary to Amir, Emily is highly positive to Islam, praising the artistic potential, beauty, and harmony of the Islamic tradition. The two main protagonists epitomize two contradictory discourses about Islam: the violent, 'medieval' law of Arab tribes on the one hand, as opposed to the peaceful, harmonious message of universal humanity on the other. These two visions collide in Amir and Emily's cross-cultural marriage.

At a given moment during a dinner party, the main setting of the play, Isaac and Emily are left alone in Amir and Emily's apartment, and the viewer understands that Isaac and Emily have been lovers. Isaac seizes the occasion to analyse a portrait that Emily has painted of Amir. The portrait is inspired by Diego Velázquez's (1599-1660) painting of his slave assistant, Juan de Pareja (1606-1670) (Rousseau 1971; Sorabella 2007). In his assessment of Emily's work, Isaac underlines that Amir will never understand her properly, and that he, Isaac, represents a better choice for her:

He doesn't understand you. He can't understand you.

He puts you on a pedestal.

It's in your painting.

Study after Velázquez.

He's looking at the viewer-that viewer is you. You painted it. He is looking at you.

The expression on that face?

Shame. Anger. Pride.

Yeah. The pride he was talking about.

The slave finally has the master's wife.

Emily: You're disgusting. ${ }^{14}$ (Akhtar 2013, pp. 69-70)

In addition to referring to the universal topos of men's rivalry over women, this passage introduces a more contentious issue, namely that of love across ethnic and religious boundaries. At this moment in the story, the cosmopolitan, inclusive ethos, which characterized the group of colleagues and friends at the beginning of the play, has been exchanged for what Akhtar in an interview refers to as tribal ways of thinking. ${ }^{15}$ The protagonists' inborn ethnic and religious identities have come to the fore, overshadowing 
their polite mundanity. Indeed, in an intersectional play with characters, Akhtar depicts Emily, the white female artist, and Isaac, the Jewish art curator, as those who set the rules of the social game. Jory, the Afro-American woman from the ghettoes, thriving as a self-made lawyer comes next; while Amir, the inborn Muslim lags behind, who, despite his mundane success, eventually is incapable of escaping his religious background.

Isaac's condescending comment with regard to Emily's portrait of Amir-'The slave finally has the master's wife' - suggests that he conceives of the relationship between them as doomed to failure, although he is himself in a cross-ethnic marriage to Jory, at the same time as he is having an affair with Emily, also across religious and ethnic divides. While the differences between Amir and Emily in Isaac's view count as an undefeatable obstacle to their relationship, the ethnic and religious differences between Emily and himself are apparently less divisive. Are they neutralised, one may wonder, by Isaac's superior position as the curator of Emily's art and key to her artistic career?

The title which Emily has chosen for her portrait of Amir, 'Study after Velázquez', produces additional and significant associations and may give further context to Isaac's evaluation of her work (and indirectly of her relationship with Amir). The reference to Velázquez's painting of his slave assistant, Juan de Pareja, points back to the history of early modern Spain and to the forced conversions and assimilation policies conducted towards Jews and Muslims living under Christian rule during that period. ${ }^{16}$ Moreover, the painting evokes an identity model where social and religious belonging is determined by blood. In early modern Spain, privilege was intrinsically linked to religious belonging, which in turn was defined in terms of the purity of your family line on both the paternal and maternal side (Ingram 2018; Hering Torres 2011; Garcia 2013). The limpieza de sangre (purity of blood) measures or laws protected the privileges of 'Old Christians', those who could prove that their ancestry was untainted by Jewish or Muslim blood. Purity of linage thus determined a person's possibility to make a public career.

In this social context, which Kevin Ingram has qualified as ridden with anxieties about purity of blood, the biography of both Diego Velázquez and Juan de Pareja stand out as significant. Both men had mixed genealogies. While de Pareja was of Morisco descent, his mother coming from a family that had been forcefully converted from Islam to Christianity in an earlier generation, Velázquez was probably of Converso origin, which means that some of his ancestors were Jewish (Ingram 2018). This made social ascent difficult for him, but through intelligent navigation in circles close to the Spanish court, and with good contacts in the Vatican - his portrait of Juan de Pareja was actually a preliminary study for his painting of Pope Innocent $X$-he finally fulfilled his ambition of entering the noble order of Santiago de Calvatera. Juan de Pareja was also able to escape his humble origin. After Velázquez freed him, he made a career as a painter on his own.

When Akthar evokes the history of early modern Spain, he draws attention to a complex interplay of religious affiliation, family lines, and social hierarchy. Does he liken Isaac with Velázquez? Both are of Jewish descent, making a career in the world of arts at the heart of Empire-the court of Golden Age Spain in the case of Velázquez, of upper Manhattan in the United States of America in the case of Isaac. In addition, are we to consider de Pareja as Amir's twin? The resemblance of the portraits suggests so. Moreover, de Pareja's social inferiority in relation to Velázquez is mirrored in the relationship between Amir and Isaac. Isaac's feeling of superiority is apparent in his evaluation of the portrait of Amir (and of Amir as a person).

Does Isaac dare to challenge Amir (with regard to Emily) because he thinks that although Emily is white and thus enjoys the privileged position of the white subject, she has no white man to protect her, and hence, she is open for grabs? If my reading is plausible, the play calls to mind the history of love across boundaries in multi-religious societies where men from the more powerful groups generally have been in the position of taking in women from the weaker groups, as David Nirenberg's seminal article, 'Love between Muslim and Jew in Medieval Spain: A Triangular Affair', convincingly argues (Nirenberg 2004). ${ }^{17}$ Nirenberg has studied primary sources from the Crown of Aragon from the late 
thirteenth to the late fifteenth century, where Muslims and Jews lived under Christian rule. He demonstrates that men from the minority group, which was favoured by the Christian overlords, could have sexual relations with women (mostly prostitutes) from the minority group that was not favoured by the Christian overlords. Which group the Christians favoured changed over time and the relative power of the minority group may be gleaned from the sources by looking at the availability of its women. The stronger the group, the more it was able to protect its women from men of the other minority group. Christian women, of course, were out of reach for both Jewish and Muslim men living under Christian rule (Nirenberg 2004). In previous centuries, however, when Muslim dynasties ruled the Iberian Peninsula, the roles were turned as we find examples of Muslim men marrying Christian women or keeping Jewish or Christian women as concubines (Zorgati 2012).

Isaac's pointing to the inadequacy of Amir's relationship with Emily almost follows the same line of reasoning as Nirenberg discloses in medieval sources: In a society where Jews are favoured over Muslims-which Akhtar suggests is the case in the US post 9/11Amir, the inborn Muslim, should never have had access to Emily, the Christian woman. It is, as Isaac bluntly affirms, unnatural that the slave marries the woman of the master. Still, the parallel with medieval Iberia is not absolute since Isaac, 'the Jew', is not prevented from having an affair with Emily. No legislation in current 'western' societies forbids relationships across ethnic or religious boundaries, which was the case in medieval Iberia, and which still is the case in several Muslim majority countries where the marriage between a Muslim woman and a non-Muslim man is not legally valid, but considered void. ${ }^{18}$ What Disgraced suggests, however, is that despite equality in legal terms, social imaginaries may reproduce similar thought patterns to those found in earlier societies.

My reading of this episode from Disgraced therefore also sheds light on the negative sentiments expressed towards Muslim men by the far-right nationalist bloggers and Facebookers studied by Fangen and Horsti. In characterizing Muslim men as uncivilized and brutal, the nationalists range them lower on the human hierarchy than they range Norwegian or Swedish girls. A relationship between a Muslim man and a Norwegian or Swedish woman is therefore contrary to nature as it transgresses biological hierarchies-or the purity of blood lines if we were to use an early modern parallel. ${ }^{19}$ In short, blonde women should be reserved for white men. The bloggers would agree with Isaac that Amir's relationship with Emily is unnatural, but they would also rule out Isaac's relationship with her. Emily, the white, blonde woman, should, in the view of the bloggers, have dated and married a white man, one of her own kind. This is love-jihad-thinking, Scandinavian style; a pattern of reasoning about human relationships that has echoes in medieval sources.

The character Emily also corresponds to the ambivalent image that far-right groups hold of majority women. As already demonstrated, in far-right rhetoric, the 'blonde woman', independent and free, may turn either into a leftist feminist who opens the country to immigration and the Muslim takeover, or into a victim of Muslim rape and violence who must be cared for and looked after by men of her own kind. Accused of neglecting the interests of the nation as well as being blind to the alleged oppression of Muslim women, non-Muslim women who show sympathy towards Islam or Muslims or demonstrate support of liberal immigration policies are qualified as false feminists and traitors; enemies from within. In Fangen's analysis, women in favour of multiculturalismthe character Emily being a case in point-challenge the binary worldview of the far right of us (white liberated Norwegian/Western women and kind white men) versus them (subjugated Muslim women and violent Muslim men) and are therefore, according to the group members, worthy of scornful speech (Fangen 2020, p. 464). In short, it seems that far right anti-Muslim discourse hovers between feminism, in the garb of femonationalism on the one hand, and anti-feminism on the other. Ayad Akhtar plays with some of these anxieties and ambiguities in his play.

The closing scene of Disgraced provides, for example, a rather grim prospect for cross-cultural love: 
Amir: I don't know if you've read any of my letters .... There's a lot you were right about me.

I'm finally seeing what you were seeing.

I'm finally understanding your work.

Emily: My work was naïve.

Amir: No, it wasn't. Why are you saying that?

Emily: Because it's true.

Amir: God. If you had any idea how sorry I am.

Emily: I know. (Akhtar 2013, p. 86) 20

Emily leaves Amir alone with the portrait she painted of him in an otherwise stripped apartment. Their relationship is over. Emily has moved out of their home after Amir, discovering that she had an affair with Isaac, beat her violently. Amir's assault is one of the most contested themes in Disgraced as it replicates the image of the violent Muslim male, who, driven by a code of honour, turns to violence when he is disgraced. Moreover, Amir is in a relationship with a white woman, thus his violence concurs with the negative visions of Islam and Muslims nurtured by the far right, responding to their deepest fears. From this vantage point, Emily is at once incarnating the multicultural liberal woman and the blonde victim of Muslim violence.

In the final scene of the play, Amir studies the portrait Emily painted of him; himself in her gaze. Both Emily and Amir are disillusioned: Emily regretting her naiveté, Amir his violence. In hindsight, when it is too late, they see the result of their respective interpretations of each other, influenced by their different assessment of Islam: Emily's humanistic version met Amir's patriarchal interpretation, epitomised by his fist. The stroke marked the ultimate limit of their respective worldviews. For Amir, it represented a possible action, for Emily an impossibility.

\subsection{Karpe}

The same year as Disgraced was performed at the National Theatre in Oslo, the celebrated Norwegian rap group, Karpe, released their new album SAS Plus/SAS pussy, a follow up of the successful Heisann Montebello-project (2015-2016) composed of live concerts, an album, music videos, and a film, Adjø Montebello. While Heisann Montebello constitutes a stark criticism of racism, xenophobia, and Islamophobia, SAS Plus/SAS Pussy contains lyrics that are more opaque and open to a broader spectrum of interpretations. In both projects, however, direct and indirect references to interfaith love appear.

Let us start with a line and an interlude from SAS Plus/SAS Pussy. The line goes as follows: 'Dodi og Diana i den bilen', ${ }^{21}$ referring to the relationship and tragic death of Dodi al-Fayad and Princess Diana in a car accident in Paris in August 1997. The interlude follows up the royal theme by telling the story of King Hussain of Jordan and the British born Antoinette Avril Gardiner, who became Princess Muna Al Hussein, the second wife of King Hussain of Jordan and mother of the present King Abdullah II. ${ }^{22}$ Magdi narrates:

Det var en britisk jente, 19 år gammel

Som jobbet på settet til Lawrence of Arabia

Så kommer det en dude ridende forbi, spottet henne

"Assalamu alaikum"

Også viste det seg at det var kongen av Jordan

Så hun satt seg bakpå, de giftet seg

Hun skiftet navn til Muna Al-Hussein

Og ble prinsesse av Jordan. ${ }^{23}$

Both stories are about powerful Muslim men who enter into relationships with white women. Dodi al-Fayad, the Egyptian businessman was the companion of Diana, the epitome of European royalty and fairy tale princess of the twentieth century, while King Hussain of Jordan married a young British woman, elevating her to the rank of princess and mother of a king. In contrast to the story of Amir and Emily, the Muslim man in these 
examples is of almost equal or higher rank than the white woman. SAS Plus/SAS Pussy thus reverts the gender/race hierarchy of Disgraced. Moreover, these stories from reality obtain an aura of legend in Karpe's universe, feeding into medieval imaginaries and ballads about Christian princesses being stolen away by Muslim knights ...

While SAS Plus/SAS Pussy mentions cross-religious or cross-cultural relationships as curiosities or as alliterations in rhythmic beats ('Dodi and Diana'), Heisann Montebello underlines the racist bias in negative attitudes towards such relationships. The song 'Kjekt å være rebell i kjellerleiligheten din' ['Nice to be a rebel in your basement apartment'] represents a stern critique of everyday racism-'Dere er alle samme ulla/Alle skal bli knulla/Mullah, mullah, mullah, mullah, mullah'; 'Plukker frukt i våre haver/Du blir aldri skandinaver/NAVer, NAVer, NAVer' ${ }^{24}$ Moreover, the lyrics target racist imaginaries about black or Muslim men 'stealing' white women from their 'legitimate future husbands':

Jeg skiter i om du er Tshawe ${ }^{25}$ eller Vinz eller Nico ${ }^{26}$

(Er det du som skal med dattera mi på kino?)

Du er kanskje kul i dag, men hun gifter seg med $\mathrm{Kygo}^{27}$

(Er det du som skal med dattera mi på kino?)

Har du hijaben i baksetet, skal hun bli muslim nå?

(Er det du som skal med dattera mi på kino?)

Jeg er ikke rasist, men skal liksom liksom-passet ditt bety noe?

(Er det du som skal med dattera mi på kino?) ${ }^{28}$

In the cited passage, the voice of the father (supposedly ethnically Norwegian), inspired by anonymous commentaries on the Internet, ${ }^{29}$ is opposed to the potential lover of the daughter, a man of colour or of different religious affiliation, epitomized by Norwegian artists of varied ethnic and religious backgrounds. While the father accepts a flirt with these artists, he insists that his daughter will end up with the ethnically white artist, Kyrre Gørvell-Dahll, alias Kygo. Like Disgraced, Heisann Montebello addresses love relationships across ethnic and religious boundaries and the power struggles they entail between males of different ethnic affiliation. Moreover, in letting anonymous voices from the Internet enter their musical universe, Karpe comments on similar attitudes as those studied by Fangen and Horsti. The passage from 'Kjekt å være rebell i kjellerleiligheten din' suggests a view according to which Norwegian daughters should marry Norwegian white men. The anonymous father thus replicates the fear expressed by nationalist bloggers about Muslim, brown men taking over their women. Hence, the song constitutes a critical comment to the Scandinavian version of the love-jihad discourse.

If Karpe plays with stereotypes and prejudices associated with interfaith love, evoking the love-jihad trope, the TV-series Norskish [Norwegianlike] adds nuance to the topic of love in multi-ethnic and multi-religious societies.

\subsection{Norskish}

The TV-series Norskish (aired 2021) follows a group of friends in Oslo through eight episodes. The main characters are young adult Norwegians with family origins in Iran, Turkey, and India, and with Islam or Sikhism as a cultural and religious backdrop. The series is about their relationships: with friends, parents, potential parents-in-law, siblings, girlfriends, boyfriends, one-night stands, children, and ex-husbands. Navigating their parents' expectations of success in family and professional life, and the Norwegian young adult culture including partying, dating, and alcohol, in addition to important workloads, they struggle to find a balance in their complex lives. Their identity work stirs associations to Homi Bhabha's concept of the 'in-between' or to different sociological theories about hyphenated and plural identities (Bhabha [1994] 2004; Sandberg et al. 2018; Østberg 2003). In this respect, the first scene of the series is programmatic: Fariba, of Iranian background, is showing her passport at the checkpoint at Gardermoen, Norway's main airport. The policeman at the counter asks her where she comes from. She ripostes, immediately annoyed, that as he may well see, she carries a Norwegian passport; despite her brown 
hair and dark eyes, she is Norwegian. The controller nods appreciatively, but repeats his question, clarifying that he needs to know from which country she has flown into Norway. Overall, the series plays with and challenges a series of stereotypes that are circulating in different social milieus in Oslo anno 2021.

Many of the main characters are having love affairs across religious and ethnic boundaries. Fariba has a son with an ethnic Norwegian man, but they are now separated, sharing custody of their child. By dividing the time spent with their child equally, they conform to the societal ideal of gender equality. Fariba thinks her husband left her because he was looking for a woman who would accompany him on ski tours and walks in the woods, eating the Norwegian hitchhiking chocolate par excellence, Kvikk Lunsj [Quick Lunch]! He claims, on the other hand, that she never opened up emotionally to him and suggests that difficulties in communication were at the heart of their separation. At the end of the series, Fariba meets a man in a bar. He is actually the passport controller from the first scene of the series. Perhaps this time, a relationship with an ethnic Norwegian will work out?

One of the other characters, Amrit, is cohabiting with an ethnic Norwegian girl, without his family knowing about it. They, especially his mother, want him to marry a woman with a background from India-preferably from the Sikh community. In order to please his mother, he accompanies her to a Sikh wedding, which he later describes as the purest meat market. For a short period, he becomes interested in a woman from the Sikh community, hoping perhaps that she will better understand the responsibility he feels for taking care of his mother. However, when his Norwegian girlfriend tells him that she has spent the entire day at the hospital accompanying her father who is suffering from a heart disorder, Amrit is forced to revise his prejudgments about cultural differences-'Norwegians' too take care of elderly parents.

After this episode, Amrit is ready to introduce his Norwegian girlfriend to his mother. He is now confident that he wants to share his life with her, and in a burst of complete honesty, he tells her about his flirtation with the Sikh woman. His girlfriend does not respond with anger, but instead seizes the occasion to tell him that she also has doubts about their relationship. However, where Amrit has emphasized cultural differences, she is more concerned that his work as a bar owner with late working hours is difficult to reconcile with children and family life. Interestingly, it is the girlfriend's mother who has come up with the argument. The series thus suggests that ethnic Norwegian mothers are not so different from the 'immigrant mothers'. They too indirectly interfere in or influence their children's choice of partner.

The third main character, Helin, has parents from Turkey; both have higher educations, the mother is working as an interpreter and the father is a university professor. The mother, who is a feminist, does not appreciate that her daughter chooses to date a man from the conservative Turkish milieu in Oslo. His parents are of a working-class background and hold on to traditional gender roles and notions of honour. For example, the potential mother-in-law is shocked when she realizes that Helin's unmarried little sister is expecting a child with her ethnic Norwegian boyfriend. The 'mother-in-law' characterizes the pregnancy of Helin's sister as a shame, but places the shame with the parents and sister of Helin (it is your family's shame), and not with her. In this way, the 'mother in law' tries to integrate Helin into the value framework of her own family.

While the 'mother in law' represents a traditional view on gender roles and honour culture, Helin's parents respond to her sister's pregnancy with enthusiasm, to Helin's surprise. While her little sister lives with her Norwegian boyfriend in the basement, Helin has kept her relationship with ethnic Norwegian men hidden from the family. The standard excuse to her mother, who keeps calling her, has been that she is staying over at Fariba's place. Helin's parents show greater acceptance/tolerance than she thought was possible. When she asks her father if her sister's pregnancy does not create problems for him, he answers: I have nothing to be ashamed of; I have two beautiful, intelligent daughters who make me proud. Helin, who for a while tried to adopt the mind-set of her 'mother-in-law', 
reaches the conclusion that 'it is a world that separates us [herself and her boyfriend]'. He agrees, and they part with respect.

Through Helin's story, the series sheds light on different value systems and worldviews that exist among families of immigrant backgrounds in Oslo-from the more conservative to the more liberal. The families of Turkish background also reflect, in a generalized manner, political and social divides in the country of origin-the secular versus the Islamist Turkey, the well-educated feminist versus the traditional woman who seeks recognition as housewife and head of the women of the extended family. Helin's mother has more in common with the ethnically Norwegian Marianne, the other expectant grandmother, than she has with Helin's 'mother-in-law'.

Norskish problematises love across ethnic, religious, and class boundaries, drawing a sympathetic picture of the relationship between parents and children, loving and difficult at the same time. It discusses individual-based versus collectivist family structures in contrasting Helin's engagement into a 'traditional Turkish family' to her sister's relationship with a Norwegian boyfriend. Amrit's mother and Helin's 'mother-in-law' are representatives of collective ideals, while Amrit, Fariba, and Helin engage in more individuallybased relationships. Still, even in individual-based families, such as the 'Norwegian' family of Amrit's girlfriend, the children take responsibility for sick parents and mothers care about their children's choice of partner. Hence, the series also questions prejudices about Norwegian majority culture as individualistic and with low esteem for family life.

Young adults with complex backgrounds must relate to and navigate between conflicting value discourses. The series suggests that this navigation does not only take place between so-called Norwegian and so-called immigrant cultures, but occurs between different worldviews within 'immigrant communities'. While some of these harmonize easily with post-modern, individualistic lifestyles, others are less compatible with such modes of life. Even Fariba's mother, who has accepted that her daughter has a child with an ethnic Norwegian man and usually takes her side in discussions with the father about how much freedom (but at the same time help and support from the family) Fariba can demand, expresses yet in despair: 'When will you understand that the children's actions affect the parents ?!' The series ends with Fariba applying to study medicine. In this way, she meets one of her parents' strongest wishes.

The main message in Norskish is perhaps that even though religion and culture count, value patterns and worldviews often cross such paths. In this, it shares insights with academic studies of young people of mixed backgrounds in Norway (Sandberg et al. 2018) and echoes the voices of the book Third Culture Kids, å vokse opp mellom kulturer [Growing up between cultures] from 2019 (Naqvi 2019).

\section{The Reception of Disgraced and the Heisann Montebello Project}

If Norskish provides a rather optimistic view on the prospect of multicultural societies, the debate that followed in the aftermath of the premiere of Disgraced in Oslo demonstrates that questions of ethnicity and religion are burning topics in mainstream media. The same holds true for the reactions that followed the launch of Karpe's 'Kjekt å være rebell i kjellerleiligheten din' and 'Attitudeproblem' - perhaps the two most controversial songs in the Heisann Montebello-project. Although the debates did not address the love-jihad discourse directly, the reception of the works of art says something about their relevance for broader sections of Norwegian society.

The theatre critic in the newspaper Aftenposten, Mona Levin, was negative in her assessment of Disgraced, finding the dialogue artificial, the intrigue predictable, and the drama outdated. According to Levin, the play contributed little to current societal debates, 'beyond that everyone has the right to define their own offense' ${ }^{30}$ (Levin, 2 September 2019). Her critique provoked the response of Ulrik Imtiaz Rolfsen, a filmmaker who has dedicated his work to questions of multiculturalism, and processes of integration and exclusion in Norwegian society (Rolfsen, 3 September 2019). According to Rolfsen, Levin 'clearly does not understand the actuality and the scope' of Amir changing his name from the Muslim 
Abdullah to the more Indian sounding Kapoor, of his choice of being an apostate from Islam, or of the reactions he experiences from majority society when being associated with an imam suspected of terrorism. ${ }^{31}$ In short, Rolfsen accuses Levin for being outdated and out of sync with the multicultural society in which she lives. Contrary to Levin, Rolfsen finds the play highly relevant and complex (Rolfsen, 3 September 2019). In her response, Levin ridicules his suggestions that she is not aware of the challenges of multicultural societies, underlining that she has fought racism and antisemitism for years. She suggests that the public at the National Theatre apparently knows more about Islam than about Judaism, and in turn accuses Rolfsen of ignorance: 'Doesn't Ulrik Imtiaz Rolfsen know that Jews do not eat pork? Doesn't he know that many Jews with Jewish or Polish names changed them to more German or American names, as the Pakistani Amir in the play changes his name to the Indian Kapoor, to be more palatable to the general public?' (Levin, 5 September 2019). ${ }^{32}$

Commenting on this debate about the relevance of the play, the author himself intervened, clarifying that although Levin was right in citing him on the play being less controversial than in 2011, she was wrong in believing that he thought the play was less relevant in 2019 than before. The opposite was actually the case. Akhtar affirmed that while the tribal identities he puts on stage in Disgraced were controversial in 2011, by 2019, in 'a world completely shaped by the events we usually refer to as " $9 / 11^{\prime \prime}$ ', they have become commonplace and thus even more relevant in 2019' (Akhtar, 10 September 2019). ${ }^{33}$ In her response to Rolfsen and Akhtar, Levin sharpens the tone, twisting the meaning of relevance and actuality:

Akthar also writes that if the play is not as current as it once was, it is more relevant than ever before, because the world changed after 9/11. Nevertheless, for other minorities the trivialised racism has been rather gruesome much longer than from 9/11 onwards. In this country, it concerns for example the Samis, the Taters, and the Jews. It seems odd to write this on the 18th anniversary of the tragic event of 9/11, the one Amir in the play has to admit that he 'is proud of'. (Levin, 12 September 2019) $)^{34}$

The debate between Ulrik Imtiaz Rolfsen and Mona Levin demonstrates, contrary to Levin's claim, that the play is highly controversial and relevant in Norway anno 2019. Just underneath the surface of Levin's and Rolfsen's sour, but still courteous exchange, tribalism lingers. The sufferings of different minorities are indirectly juxtaposed, as Rolfsen suggests that Levin is blind to the sufferings of the Muslim minority, while she ripostes that what Muslims suffer now other minorities have suffered before and still do. Ironically, both appear to be offended [krenket], thus responding to the Norwegian title given to the play. The translator chose krenket rather than vanæret, which would have been the more literal translation of 'disgraced'. Hence, the Norwegian title plays into the societal discourse about identity culture and offence rather than into the discourse about shame and honour.

Karpe's engaged lyrics and pictorial universe have also created reactions in the public debate. Members of the youth organisation of the Norwegian Progress Party [Fremskrittspartiet] were furious after the rap group ridiculed their minister, justice minister Anders Anundsen in 'Kjekt å være rebell i kjellerleiligheten din', but also people closer to Karpe on questions of racism and xenophobia have been perplexed by their provocations. In the song 'Attitudeproblem', Karpe includes 'Jew' in a series of negatively laden words such as bitch, whore, slut, and dick; a move that created strong reactions from the Mosaic community in Oslo. In a newspaper comment, the leader of the community, Ervin Kohn, first pointed to his shared agenda with Karpe in the fight against racism and xenophobia, but then argued that their lyrics in 'Attitudeproblem' miss the mark (Kohn, 18 April 2016). ${ }^{35}$ Karpe's female colleagues in the music industry also demonstrated their anger against the group's misogynist lyrics. In a remix of the song, well known Norwegian artists such as Izabell, Bendik, Stella Mwangi, Silvana Imam, Julie Bergan, and Christine Dancke play with masculine rap stereotypes in general and with Karpe's use of them in particular, 
commenting, for example, on how young male artists in order to succeed must ingratiate themselves with the older, experienced, and well-connected guys in Karpe. ${ }^{36}$

\section{Conclusions: Genealogical Thinking}

Disgraced, Heisann Montebello, SAS plus/SAS pussy, and Norskish represent challenges related to love, family, mixity, religion, and identity in twenty-first century multicultural societies. For example, the undercurrent in Akthar's play is that the most loaded identity in the US post 9/11 is the Muslim one. The debate among theatre critics in the wake of the staging of the play in Oslo suggests that questions of vulnerable minority identities also are of current interest in the Norwegian context. The uncomfortable nature of such questions is highlighted in Akhtar's play through references to early modern Spain and the limipeza de sangre measures, which placed the religious belonging of a person in his blood and genealogy. Akhtar, who lets Amir think of religious identity in biological terms, refers to this form of identity construction as tribalism, while Karpe recognizes similar structures in the voice of the anonymous father on the Internet who, although accepting a flirt with Vinz or Nico, eventually will give his daughter to Kygo (supra, p. 9).

In my view, these examples of 'tribal thinking' are closely connected to the love-jihad discourse, as this discourse only has meaning in a thought system where the social group (for example the Hindu or the Nordic nation) is defined in genealogical terms and where the bodies of women constitute the limit of the respective groups. 'Tribal thinking' is succinctly put in Amir's comment about religious identity, 'it is in your blood', but also more subtly present in Norskish: in Helin's unfounded fear of her parents not accepting a Norwegian boyfriend, in her 'mother in law's' wish for an honourable wife for her son, or in Amrit's mother's wanting him to marry a Sikh girl. More brutally, a variant of 'tribal thinking' is articulated in far-right anti-Muslim rhetoric, which is closely linked to biological racism. Horsti underlines that although Islamophobia 'can be seen as an exemplary case of cultural racism ..., where the incompatibility of people is defined by presumed differences in culture rather than biology ... biological racism entangles with cultural arguments in Islamophobic ideology' (Horsti 2017, p. 1442). Hence, in Islamophobic discourses the idea of biological racism also lies close at hand.

It therefore comes as no surprise that at the intersection of biological racism and cultural fear which characterises current Islamophobic imaginaries, the female body plays a prominent role. According to Horsti, for Nordic nationalists who see globalization and migration, feminism, and multiculturalism as threats to their own security and existence, 'the White female represents the border of territory, family, race, culture, and identity. Furthermore the "openness" and softness of the female body is represented as weakness, a boundary for which violation and infection from the outside are constant threats' (Horsti 2017, p. 1449). We may say that the female body has functioned as a 'boundary-maintaining mechanism', to cite a concept coined by the historian of medieval Iberia, Thomas F. Glick (Glick and Pi-Sunyer 1969; Zorgati 2012). The woman's body drew the ultimate line between religious groups in the imperial model of medieval and early modern Iberia; the female body signified the nation in the nineteenth century, ${ }^{37}$ and still has a boundarymaintaining function in the imaginaries of far-right nationalist movements of the twentyfirst century. The woman's body as boundary explains the nationalists' fear of Muslim men as well as their wish to protect their 'own women'. It also sheds light on the groups' negative attitude towards pro-multicultural, immigration-liberal versions of feminism, which, according to the groups, hinder Nordic men in expressing their sound and natural masculinity (Horsti 2017, p. 1441). As they favour pluralism and multiculturalism and do not fear hybridity or mingling, feminists more profoundly contest the idea of the homogenous, pure nation. In Horsti's words: 'The imagined double-binding threat of a hyper-masculine/emasculated Muslim male intertwines with the notion that feminism, liberal secular values, and multiculturalism would allow, and even invite, the evil to enter the nation through the female body' (Horsti 2017, p. 1450). In addition, feminism and 
the Scandinavian ideology of gender equality has produced diminished or effeminate masculinity (Horsti 2017, p. 1451).

According to this line of reasoning, feminism is responsible for the inability of Scandinavian men to protect their own women from foreign assault. The attack on the Swedish woman studied by Horsti may therefore be understood as an attack on Swedish men. Indeed, Fjordman understood the 'rape epidemic' in terms of warfare: 'It's not 'crime', but in fact resembles warfare ... If you postulate that many of the Muslims in Europe view themselves as a conquering army and that European women are simply war booty, it all makes perfect sense and is in full accordance with Islamic law' (Horsti 2017, p. 1450, citing Fjordman, 'Immigrant rape wave in Scandinavia', 12 December 2005). Fjordman's comment represents a variant of the patriarchal nexus that I mentioned in the beginning of this article, and which also underpins Isaac and Amir's fight over Emily. Men who are unable to protect their women from foreigners are regarded as inferior, which explains why armies throughout history have used sexual violence to degrade and humiliate the enemy. Rape has been, and still is, an effective weapon. By inseminating the women of the enemy, victorious masculinity demonstrates who is in charge of the territory (Pitt-Rivers 1977; Mirrer 1996; Zorgati 2012). The fear expressed by Nordic nationalists in circulating the meme of the assaulted blonde woman is thus as old as the existence of competing patriarchal cultures.

Twenty-first century anti-Islamic discourses fear Muslims as alien elements to the national body, emphasizing that 'biological ancestry is the only way to become part of the nation' (Fangen 2020, p. 455); hence white women, who bear the nation's children, must be protected from the pollution of Muslim seed. In short, the fear of interfaith love involving 'one's own women', which is addressed in Genesis ${ }^{38}$ and which structured medieval and early modern plural societies, is still echoed in the twenty-first century. Only from this vantage point may men from other groups be perceived as threats and the love-jihad discourse have an appeal.

Read intertextually and in light of recent research in sociology and media studies, Disgraced, Heisann Montebello, SAS plus/SAS pussy, and Norskish demonstrate that the love-jihad discourse exists in Scandinavia. It is directly articulated in far-right blogs and Facebook groups and indirectly present in the works of art and popular culture that I have explored in this article. These works discuss different aspects of Islamophobia and through various representations of cross-cultural love, they evoke the issue of 'tribalism' and themes affiliated to the love-jihad nexus. While the blogs and Facebook groups may be qualified as semi-public arenas, which mainly engage particular fringes of society, the works of art and popular culture target mainstream audiences in Norway. The different publics who visit the National Theatre in Oslo, enjoy Karpe's concerts, or relax in front of a TV-series aired by the national public broadcaster, have all witnessed topics that indirectly relate to the love-jihad discourse. Hence, the patriarchal pattern of the love-jihad discourse lives on in gender egalitarian post-modern Scandinavia.

Funding: This research received no external funding.

Institutional Review Board Statement: Not applicable.

Informed Consent Statement: Not applicable.

Data Availability Statement: Not applicable.

Conflicts of Interest: The author declares no conflict of interest.

\section{Notes}

1 Scholarship on Islam in Europe has primarily studied Islam's presence in Western Europe after World War II, seeing it as a consequence of labour migration, refugee or asylum seeking, and family reunion programs (Nielsen and Otterbeck [1992] 2015). Emphasis has been put on normative religious practice and the establishment of Muslim institutions in Europe (for example, Vogt 2008; Laurence 2012), on gender, identity, and generational issues (for example, Roald 2001; Jacobsen 2002; Bøe 2019). The study of everyday religion among Muslims displaying different levels or forms of religiosity and different degrees of affiliation 
to institutionalized religion has also been in focus (for example, Brubaker 2013; Dessing et al. [2013] 2016; Sandberg et al. 2018; Østberg 2003). In addition, scholarship on Islam in Europe has increasingly explored Islam's historical presence on European soil or cultural encounters between Europe and the Islamic world (for example, Tolan et al. 2013; Dakhlia and Vincent 2011, 2013). There exists an important literature on Christian, Jewish, and Muslim communities in medieval and early modern Iberia, and several studies are aimed at establishing the historical presence of Muslims in different European nation states or the relationship between that nation state and the world of Islam (for example, Coller 2011; Simonsen 2004; Sorgenfrei 2018). Finally, scholarship of the last ten years on Islam in Europe has increasingly addressed the issue of art and popular culture (Peter et al. 2013; Jouili 2013, 2019).

2 For studies on popular culture in the Muslim world at large, see Van Nieuwkerk et al. (2016) and Van Nieuwkerk (2012).

3 University of Oslo, https://www.hf.uio.no/iakh/forskning/aktuelt/arrangementer/studentarrangementer/2019/fobier-ogforfolgelse.-antisemittisme-og-islamofob.html, 17 October 2019, accessed on 28 October 2021.

4 For an introduction to Karpe's work, see Holen (2018) and Karpe Diem and Akam1k3 (2013). For a study of the reception of Karpe's music among Muslim youth, see Jacobsen and Vestel (2018).

5 Among a long list of prestigious prises, Karpe has been awarded Spellemannsprisen, the most important Norwegian music prise for Heisann Montebello (best album) in 2016 and for SASPlus/SASPussy (best album) in 2019. For an updated list, see https://no.wikipedia.org/wiki/Karpe_(musikkgruppe), accessed on 1 November 2021.

6 Other series are 16,17,18,19, or Skitten snø [Dirty snow] based on the novel of the same name by Mahmona Khan (2011).

7 As explained to me by one of the authors in a conversation in Oslo the autumn of 2019.

8 Ragnhild Johnsrud Zorgati and Cecilie Endresen. Mobile Muslims and Invisible Islam. University of Oslo, https: / / www.hf.uio.no/ ikos/english/research/projects/mobile-muslims-and-invisible-islam/, accessed on 28 November 2021.

9 Both groups were public when Fangen conducted her non-participant fieldwork in 2017, but have since become closed. Their open nature was an asset from Fangen's point of view, as she wanted to shed light on the mainstreaming of anti-Islamic ideas more than delving into the hidden corners of the dark web.

10 This quotation brings to mind the plot of the Danish novel Det europxiske forår [The European Spring] by Kaspar Colling Nielsen (2017): Denmark purchases land in Mozambique where they establish a colony for deported Muslims. The State has given its Muslim inhabitants the choice between assimilating into 'Danish' neighborhoods, leaving the ghettos of the big cities, or deportation to Mozambique. Those who refuse assimilation are expelled from Denmark. I cite Akhtar's original in the main text and the Norwegian translation in the footnotes.

Akhtar was rewarded the Pulitzer Prize for Best Drama in 2013. For a thorough analysis of Akhtar's work, see Basu (2019). American short hand for White Anglo-Saxon Protestants associated with the privileges historically held by this group.

'Han forstår deg ikke. Han kan ikke forstå deg. Han setter deg på en pidestall. Det vises i portrettet. Studie etter Velazquez. Han ser på betrakteren—og den betrakteren er deg. Du malte det. Han ser på deg. Uttrykket i ansiktet hans? Skam. Sinne. Stolthet. Ja. Stoltheten han snakket om. Slaven har endelig fått sin herres kone. Emily: "Du er faen meg drøy"' (Scene 3, p. 109 in Norwegian manuscript, translated by Agnes Banach).

15 Akhtar comments upon his play in the newspaper Aftenposten: 'Forestillingen "Krenket" er mindre kontroversiell, men mer relevant. Dramatiker svarer anmelder', Aftenposten, 10 September 2019, accessed on 28 October 2019, https: / / www.aftenposten. no/meninger/debatt/i/awL1rA/forestillingen-krenket-er-mindre-kontroversiell-men-mer-relevant.

For more on the history of Muslims living under Christian rule in early modern Iberia, see for example Harvey (2005) and Perry (2005).

Mirrer (1996), using examples from the Crown of Castile and Pitt-Rivers (1977), citing Genesis, also demonstrate how men from the stronger group take in women from the weaker one.

18 Tunisia lifted the ban on intermarriage for women in 2017 and was the first country in the Middle East and North Africa to do so. Rana Jawad, Tunisian Women Free to Marry Non-Muslims, BBC News, 15 September 2017, accessed on 1 November 2012, www.bbc.com/news/word-africa-41278610.

19 Scholars debate whether modern forms of racism and Islamophobia can be traced back to the imaginary constructions surrounding purity of blood regulations in early modern Iberia. See for example Hering Torres (2011) and Soyer (2012).

““Jeg vet ikke om du har lest brevene mine... Det var mange ting du hadde rett i om meg. Nå ser jeg det du ser. Endelig forstår jeg arbeidene dine". Emily: "Arbeidene mine var naive". Amir: "Det var de ikke. Hvorfor sier du det?" E: "Fordi det er sant". A: "Herregud, Emily. Hvis du visste hvor mye jeg angrer" E: “Jeg vet det"' (p. 132 in Norwegian manuscript). 'Dodi and Diana in that car'. I cite the original Norwegian in the main text and give the English translation in the footnotes.

"Just who is Princess Muna Al Hussein of Jordan?", Salon Privé Magazine, 1 June 2021, accessed on 10 August 2021, https: / / www.salonprivemag.com/princess-muna-al-hussein-of-jordan/.

23 'There was this British girl, 19 years old; Who worked on the set of Lawrence of Arabia; Then a guy comes by on a horse, spots her; "Assalamu alaikum"; And then it turned out that it was the king of Jordan; So she mounted behind him, they got married; She changed her name to Muna Al-Hussein; And became princess of Jordan'. My translation. 
'You are all of the same stuff/Everyone gets fucked/Mullah, mullah, mullah, mullah, mullah'; 'Picking fruit in our garden/You'll never be Scandinavian/NAVer, NAVer, NAVer'. Translation by Therese Sjøvoll. The term NAVer refers to a person who is dependent on public welfare. It is constructed from NAV, the abbreviation for the Norwegian Labour and Welfare Administration. Tshawe Baqwa, internationally acclaimed rapper from the rap-duo Madcon. Vincent 'Vinz' Dery and Nicolay 'Nico' Sereba from Holmlia i Oslo form the successful rap-duo Nico \& Vinz. Artistic name of Kyrre Gørvell-Dahll, here incarnating the successful Norwegian artist of Norwegian descent.

'I don't give a fuck if you're Tshawe or Vinz or Nico/(Are you the one taking my daughter to the movies?)/You might be cool today, but she's marrying Kygo/(Are you the one taking my daughter to the movies?)/Do you have the hijab in the back seat, is she gonna be Muslim now?/(Are you the one taking my daughter to the movies?)/I'm not racist, but is your pretend-passport supposed to mean anything?/(Are you the one taking my daughter to the movies?)'. Translation by Therese Sjøvoll. Karpe underlines in several interviews that many of their texts are inspired by discussions and commentaries on the net. 'utover at alle har definisjonsrett til sin egen krenkelse': Mona Levin, 'Identitetspolitikk, religion og fennikelsalat. Flat replikkføring hindrer dypere forståelse av allerede utdatert moderne drama', Aftenposten, 2 September 2019, accessed on 28 January 2021, https: / www.pressreader.com/norway/aftenposten/20190902/281960314427184. My translation.

31 Ulrik Imtiaz Rolfsen, 'Anmelder: Publikum reagerte feil!' Aftenposten, 3 September 2019, accessed on 28 October 2019, https: / / www.aftenposten.no/meninger/debatt/i/Joq9nb/anmelder-publikum-reagerte-feil-ulrik-imtiaz-rolfsen. My translation.

32 'Vet ikke Ulrik Imtiaz Rolfsen at jøder ikke spiser svin? Vet han ikke at mange jøder med russiske og polske navn byttet til mer tyske eller amerikanske navn, slik pakistanske Amir i stykket bytter til det indiske Kapoor, for å bli mer spiselig i offentligheten?' Mona Levin, 'Har dramatikeren fasiten, Rolfsen?', Aftenposten, 5 September 2019, accessed on 28 October 2019, https:/ / www.aftenposten.no/meninger/debatt/i/dOpV6z/har-dramatikeren-fasiten-rolfsen-mona-levin? My translation.

33 'Vi befinner oss nå i en verden som er helt formet av begivenhetene vi pleier å vise til som "9/11"': Ayad Akhtar, 'Forestillingen "Krenket" er mindre kontroversiell, men mer relevant. Dramatiker svarer anmelder', Aftenposten, 10 September 2019, accessed on 28 October 2019, https: / / www.aftenposten.no/meninger/debatt/i/awL1rA/forestillingen-krenket-er-mindre-kontroversiellmen-mer-relevant. My translation.

34 'Akhtar skriver også at om stykket ikke er så aktuelt som det var, er det mer relevant enn noen gang, fordi verden er endret etter 9/11. Men for andre minoriteter har den trivialiserte rasismen vært ganske grusom mye lenger enn fra $9 / 11$. I dette landet gjelder det for eksempel samer, tatere og jøder. Det føles merkelig å skrive dette på 18-årsdagen for den tragiske hendelsen 9/11, den Amir i stykket må innrømme at han "er stolt av"'; Mona Levin, 'Vranglesing og oversetterfeil', Aftenposten, 12 September 2019, accessed on 28 October 2019, https://www.aftenposten.no/meninger/debatt/i/qLXRjw/vranglesing-og-oversetterfeil-mona-levin. My translation.

35 Ervin Kohn, “Kjære Karpe Diem: Spill inn Attitudeproblem på nytt.” Aftenposten, 18 April 2016, accessed on 2 November 2021, https:/ / www.aftenposten.no/meninger/debatt/i/4dq7R/kjaere-karpe-diem-spill-inn-attitudeproblem-paa-nytt-ervin-kohn.

36 Karpe Diem feat Izabell, Bendik, Stella Mwangi, Silvana Imam, Julie Bergan and Christine Dancke-Attitudeproblem, NRK P3 Remix, 29 April 2016, accessed on 1 November 2021, https: / / www.youtube.com/watch?v=03-8exSu6jg.

37 In the history of European nationalisms, women incarnated the nation, metaphorically in figures such as the French 'Marianne' or the Danish 'Mother Denmark,' painted by Elisabeth Jerichau-Baumann in the second part of the 19th century, practically in the idea that women, through childbirth and child raising formed the future of the nation. This idea was not only popular among 19th century Europeans, but also favoured by Arab nationalists at the turn of the century. In their defence of women's right to education, the rationale was that women needed education in order to be good mothers. Only educated women would produce qualified future citizens who could oppose European colonialism and build free and independent Arab and Muslim nations (Zorgati, forthcoming). Julian Pitt-Rivers analyses Genesis 34:1-26 in his tracing of the ban on intermarriage for women. See Pitt-Rivers (1977).

\section{References}

Akhtar, Ayad. 2013. Disgraced. New York: Back Bay Books.

Bakhtin, Mikhail Mikhălovich. 2002. Speech Genres and Other Late Essays. Edited by Caryl Emerson and Michael Holquist. Translated by Vern W. McGee. Austin: University of Texas Press. First published 1986.

Basu, Lopamudra. 2019. Ayad Akthar, the American Nation, and Its Others after 9/11: Homeland Insecurity. New York and London: Lexington Books.

Bhabha, Homi. 2004. The Location of Culture. New York: Routledge. First published 1994.

Bøe, Marianne Hafnor. 2019. Feminisme i Islam. Oslo: Universitetsforlaget.

Brubaker, Rogers. 2013. Categories of Analysis and Categories of Practice: A Note on the Study of Muslims in European Countries of Immigration. Ethnic and Racial Studies 36: 1-8. [CrossRef]

Coller, Ian. 2011. Arab France: Islam and the Making of Modern Europe, 1798-1831. Berkeley: University of California Press.

Dakhlia, Jocelyne, and Bernard Vincent. 2011. Les Musulmans Dans l'Histoire de l'Europe. Vol. 1: Une Intégration Invisible. Paris: Albin Michel. 
Dakhlia, Jocelyne, and Bernard Vincent. 2013. Les Musulmans dans l'Histoire de l'Europe. Vol. 2: Passages et Contacts en Méditerranée. Paris: Albin Michel.

Dessing, Nathal M., Nadia Jeldtoft, Jørgen Nielsen, and Linda Woodhead, eds. 2016. Everyday Lived Islam in Europe. New York: Routledge. First published 2013.

Endsjø, Dag Øistein, and Liv Ingeborg Lied. 2011. Det Folk vil ha: Religion og Populærkultur. Oslo: Universitetsforlaget.

Fangen, Katrine. 2020. Gendered Images of Us and Them in Anti-Islamic Facebook Groups. Politics, Religion E Ideology 21: 451-68. [CrossRef]

Frydenlund, Iselin, and Eviane Leidig. Forthcoming. Introduction: "Love Jihad": Sexuality, Reproduction and the Construction of the Predatory Muslim Male. Religions.

Garcia, Manuel Perez. 2013. El pensamiento europeo sobra la revisión y moderación en los estatutos de limpieza de sangre a través de la razón de estado cristiano en tiempos de Felipe IV. Bulletin for Spanish and Portuguese Historical Studies 38: 39-60. [CrossRef]

Glick, Thomas F., and O. Pi-Sunyer. 1969. Acculturation as an Explanatory Concept in Spanish History. Comparpative Studies in Society and History 11: 136-54. [CrossRef]

Göle, Nilüfer. 2013. Introduction: Islamic controversies in the making of European public spheres. In Islam and Public Controversy in Europe. Edited by Nilüfer Göle. Burlington: Ashgate, pp. 3-20.

Harvey, Leonard Patrick. 2005. Muslims in Spain, 1500 to 1614. Chicago: University of Chicago Press.

Hering Torres, Max S. 2011. La limpieza de sangre. Problemas de interpretación: Acercamientos históricos y metodológicos. Historia Critica 45: 32-55. [CrossRef]

Holen, Øyvind. 2018. Nye HipHop-Hoder: Hvordan Karpe Diem og generasjon 1984 tok en Undergrunnskultur til Pophimmelen-Og Endret Norge på Veien. Bergen: Vigmostad \& Bjørke.

Horsti, Karina. 2017. Digital Islamophobia: The Swedish Woman as a Figure of Pure and Dangerous Whiteness. New Media E Society 19: 1440-57. [CrossRef]

Ingram, Kevin Ingram. 2018. Converso Non-Conformism in Early Modern Spain: Bad Blood and Faith from Alonso de Cartagena to Diego Velázquez. London: Palgrave Macmillan.

Jacobsen, Christine M. 2002. Tilhørighetens mange former: Unge muslimer i Norge. Oslo: Unipax.

Jacobsen, Christine M., and Viggo Vestel. 2018. 'Look into My Eyes': Music, Religion, and the Politics of Muslim Youth in Norway. Journal of Muslims in Europe 7: 47-72. [CrossRef]

Jouili, Jeanette S. 2013. Halal Arts: Censorship or Creative Ethical Practice? In Islam and Public Controversy in Europe. Edited by Nilüfer Göle. Burlington: Ashgate, pp. 137-49.

Jouili, Jeanette S. 2019. Islam and Culture: Dis/junctures in a Modern Conceptual Terrain. Comparative Studies in Society and History 61: 207-37. [CrossRef]

Karpe Diem and Akam1k3. 2013. Dødtid: Bilder og Turnenotater. Oslo: Aschehoug.

Khan, Mahmona. 2011. Skitten snø. Oslo: Aschehoug.

Laurence, Jonathan. 2012. The Emancipation of Europe's Muslims: The State's Role in Minority Integration. Princeton: Princeton University Press.

LeVine, Mark. 2020. Music and the Aura of Revolution. Special Issue: Maghrebi Histories in the Modern Era. International Journal of Middle East Studies 44: 794-97. [CrossRef]

Lundby, Knut. 2017. Mediebruk og konflikter om religion i Norge. Norsk Medietidsskrift 24: 1-19. [CrossRef]

Mirrer, Louise. 1996. Women, Jews and Muslims in the Texts of Reconquest Castile. Studies in Medieval and Early Modern Civilization. Ann Arbor: University of Michigan Press.

Naqvi, Aon Raza, ed. 2019. Third Culture Kids. Oslo: Gyldendal.

Nielsen, Jørgen S., and Jonas Otterbeck. 2015. Muslims in Western Europe, 4th ed. Edinburgh: Edinburgh University Press. First published 1992.

Nielsen, Kaspar Colling. 2017. Det europæiske forår. København: Gyldendal.

Nirenberg, David. 2004. Love between Muslim and Jew in Medieval Spain: A Triangular Affair. In Jews, Muslims and Christians in and around the Crown of Aragon: Essays in Honour of Professor Elena Lourie. Edited by Harvey Hames. Leiden and Boston: Brill, pp. 127-55.

Østberg, Sissel. 2003. Muslim i Norge: Religion og Hverdagsliv Blant Unge Norsk-Pakistanere. Oslo: Universitetsforlaget.

Perry, Mary Elisabeth. 2005. The Handless Maiden: Moriscos and the Politics of Religion in Early Modern Spain. Princeton and Oxford: Princeton University Press.

Peter, Frank, Sarah Dornhof, and Elena Arigita, eds. 2013. Islam and the Politics of Culture in Europe: Memory, Aesthetics, Art. Bielefeld: Transcript.

Pitt-Rivers, Julian. 1977. The Fate of Shechem or the Politics of Sex: Essays in the Anthropology of the Mediterranean. Cambridge: Cambridge University Press.

Putri, Alyssa Syahmina, and Herlin Putri Indah Destari. 2019. On the Orientalism and Neo-Orientalism in Ayad Akhtar's Disgraced: Analysis on the Dynamics of Amir and Emily's Relationship. Humaniora 31: 282-92. [CrossRef]

Roald, Anne Sofie. 2001. Women in Islam: The Western Experience. London and New York: Routledge.

Rousseau, Theodore. 1971. Juan de Pareja by Diego Velázquez: An Appreciation of the Portrait. The Metropolitan Museum of Art Bulletin 29: 449-51. [CrossRef] 
Sandberg, Sveinung, Jan C. Andersen, Tiffany L. U. Gasser, Marius Linge, Idil A. A. Mohamed, Samah A. Shokr, and Sébastien Tutengs. 2018. Unge Muslimske Stemmer: Om tro og Ekstremisme. Oslo: Universitetsforlaget.

Sandve, Birgitte. 2015. Unwrapping 'Norwegianness': Politics of difference in Karpe Diem. Popuar Music 1: 45-66. [CrossRef]

Simonsen, Jørgen Bæk. 2004. Islam med Danske øjne: Danskeres syn på islam Gennem 1000 år. København: Akademisk.

Sorabella, Jean. 2007. Portraiture in Renaissance and Baroque Europe. Heilbrunn Timeline of Art History. August. Available online: https:/ / www.metmuseum.org/toah/hd/port/hd_port.htm (accessed on 21 October 2019).

Sorgenfrei, Simon. 2018. Islam i Sverige—De Första 1300 Åren; Bromma: Myndigheten för stöd till trossamfund (SST). Available online: https:/ / www.myndighetensst.se/kunskap/religionsliv---en-kunskapsbank-om-trossamfund-och-religion/islam-ochmuslimer/islam-i-sverige---de-forsta-1300-aren.html (accessed on 15 October 2021).

Soyer, François. 2012. Faith, Culture and Fear: Comparing Islamophobia in Early Modern Spain and twenty-first Century Europe. Ethnic and Racial Studies 36: 399-416. [CrossRef]

Tolan, John, Gilles Veinstein, and Henry Laurens. 2013. Europe and the Islamic World: A History. Princeton: Princeton University Press.

Van Nieuwkerk, Karin, ed. 2012. Muslim Rap, Halal Soaps, and Revolutionary Theater: Artistic Developments in the Muslim World. Austin: University of Texas Press.

Van Nieuwkerk, Karin, Mark LeVine, and Martin Stokes, eds. 2016. Islam and Popular Culture. Austin: University of Texas Press.

Vogt, Kari. 2008. Islam på Norsk. Oslo: Cappelen Damm.

Zorgati, Ragnhild Johnsrud. 2012. Pluralism in the Middle Ages: Hybrid Identities, Conversion, and Mixed Marriages in Medieval Iberia. New York and London: Routledge.

Zorgati, Ragnhild Johnsrud. Forthcoming. Intertwined Histories: Muslim Domesticity and the Harem in the Eyes of a Swedish Nineteenth-Century Protestant Feminist. Journal of Feminist Studies in Religion. 